\title{
Green Campus Environmental Design Based on Sustainable Theory
}

\author{
Feng Qian and Li Yang
}

\begin{abstract}
The concept of green building has been widely accepted after many years' research and development, further many scholar are promoting the combination of green building design and environmental design, especially in the field of sustainable campus design. School is an important organic component of our society, not only playing special missions of cultivating students and general public in environmental education and life-long education, but also being a system as residential district with consumption of resources and energy. Therefore, it is necessary to study campus environmental design methods based on sustainable theory, providing some scientific references for sustainable development of the whole society. The main work of this article is shown as follows: (1) Based on literature review method, this article has summarized development progress of sustainable campus design and pointed out the three basic visual angles when establishing and enhancing school facilities. (2)With regard to school planning and architectural design, some issues existing in sustainable campus design as well as their reasons have been analyzed. Meanwhile, some recommendations and suggestion for improving sustainable environmental design have been put forward. (3) Based CFD simulation method, a case study has been conducted to improve school environment and provide some references to promote sustainable school development.
\end{abstract}

Index Terms-Campus environmental design, Sustainable development, Green campus design, CFD simulation.

\section{INTRODUCTION}

Modern green buildings are generally defined as constructions that could both maximize resources (including energy, land, water and materials) efficiency and reduce environmental loads in the whole building lifecycle from material production to architecture planning and design, from construction to operation, and even demolishment [1]. In order to preserve environment and reduce pollution, and further provide human beings with healthy, applicable and high-efficient living space, green buildings are always made natural harmonious co-existence with a series of advanced resource-saving technologies [2], such as natural ventilation, natural lighting, low carbon building envelope structures, renewable energy utilization, water recycle and reuse, green building materials, intellectual control and green configuration, etc. Therefore, current green buildings are equipped with several characteristics of reasonable planning, efficient recycling of resources, comprehensive and effective energy-saving measures, healthy and comfortable building environment, harmless and decreasing emissions, flexible and

Manuscript received May 2, 2017; revised August 13, 2017.

Feng Qian is with the Department of Architecture, Tongji University, China (e-mail: qianf_caup@163.com). suitable building functions. Since the establishment green building design theory [3], it has received energetic support and fully understanding from governments and general publics all over the world. Concept of sustainable development, meanwhile, has become a consensus, promoting the combination of green building design and environmental design, with some achievements in both theoretical and practical fields. However, for sustainable campus environmental design [4], the application of green building in school environments has just started; practical experience therefore remained to be further strengthened.

This article firstly summarizes the importance and development progress of sustainable campus design and points out the three basic visual angles when establishing and enhancing school facilities. Secondly, from the perspectives of school planning and architectural design, some issues existing in sustainable campus design and some possible reasons were analyzed. Based on the above analysis, some meaningful suggestions and recommendation in terms of environmental design are provided. In order to provide some practical experience, Section IV taking a secondary school in Wuhu, China as an example, studies the school wind environment, aiming to improve school environment and promote sustainable school development.

\section{Development of Sustainable Campus ENVIRONMENTAL DESIGNS}

As mentioned in Reference [5], school, the center of the community, is an important organic component of our society, playing special missions of cultivating students and general public from the perspectives of environmental education and life-long education. School, at the same time, is a system as residential district with consumption of resources and energy. Therefore, schools should become agency that is "responsible" to environment, showing an effective role of education demonstration. Namely, it is the cornerstone of a broader sustainable development to implement the strategies of resource-saving, energy efficiency and pollution controlling within the scope of campus. Through exhibiting energy and resources saving strategies adopted in architectural design and environmental design, schools can lead private architectures to realize sustainable development, so as to set good examples for other categories of organizations. In October, 1990, presidents from 20 famous universities around the world signed Talloire Declaration in France [6], marking the beginning of the green university campus project, and almost 300 universities and colleges participated in this campaign due 2003 [7]. Research on green school and campus meanwhile has been gradually conducted 
all over the world, the progresses however are quite different due various national circumstances. Main research work carried out due 2005 could be divided into three items, as shown in Table I.

TABLE I: RESEARCH WORK CONDUCTED ABOUT GREEN CAMPUS DESIGN BEFORE 2005

\begin{tabular}{ll}
\hline \hline Items & Work and Achievements \\
\hline & (1) Kellyn analyzed the first one green school
\end{tabular}

(1) Kellyn analyzed the first one green school project "Green Scientific Museum" established by Montana State University in terms of design method, green technology and materials.

(2) Prats \& Chillon discussed water use in university campus from engineering problems aspect.

(3) Mason et al. introduced zero waste management

Theoretical and technical studies

Ecological campus construction examples

Green school evaluation system

\section{plan in a university campus in New Zealand.}

(4) In order to promote ecological education, Clay put forward four suggestions to convert environmental management policies and plans to landscape protection actions.

(5) Wasley presented experience about Gaylord Nelson House environmental design, providing reference for green school project development under different school institutional frameworks.

(1) Sculpture Gallery \& Studio in Yale university considered impacts of buildings and surrounding material-cedar-adaptable to surrounding environment. In addition, sun-shade control system and three layers of Low-E glass curtain wall and other energy saving measures were adopted.

(2) Interdisciplinary Science Museum Building in Arizona State University adopted sustainable design methods to fully employ natural ventilation and natural lighting.

(1) State of Campus Environment was widely used in the United States, which assesses sustainable through questionnaires and statistical reports.

(2) Campus Sustainability Report CARDS was widely applied in North America. It mainly uses questionnaire to evaluate the campus environment, environment: the application of recycled education, environment and operation management material recycling and students' participation.

(3) Sustainability Tracking, Assessment, \& Rating System (STARS) was used throughout the world. It mainly assesses education and research, environmental control, planning and management, public participation and innovation measures, etc.

Sustainable campus construction has also received sufficient attention in developing countries, especially several universities and research institutions, including Tongji University, Zhejiang University, South China University of Technology, Jiangnan University, Tianjin University, Chongqing University, Shandong Jianzhu University, The Hong Kong Polytechnic University, China Architecture Design Institute and Shenzhen Institute of Building Science in 2011 created the team titled China Green University Network (CGUN) [8], aiming to strengthen exchanges and cooperation in the field of green campus construction between colleges and universities, form platform experience sharing and resources complementary, so as to lead and push forward the sustainable development of green university construction in China. CGUN league has discussed many topics such as cooperation alliance, campus energy management policy, science and technology innovation, green campus personnel training and practice demonstration, green campus culture, resulting in the deepening of Chinese green campus construction. "Twelfth five-year" building energy-saving special planning jointly issued by Ministry of Housing and Urban-Rural Development in 2012 specifically mentioned sustainable campus construction pilot project, which aims to establish 72 key green universities in three stages.

More recently, a conference about environmental management for sustainable universities with the objective of exploring a more sustainable method to promote the sustainable education was held in Turkey, 2013 [9]. After the joint participation of a large number of scholars, following issues and topics related to green university project have been discussed.

(1) Goal: With the efforts made by experts and engineers in the field of sustainable development, the requirements and demands of human beings could be satisfied.

(2) Procedure: Establish the outlines and patterns of sustainable university through various different forms of documents and activities, such as declarations, charters, partnerships and conferences.

(3) Results: Implement sustainable university projects, so as to combine sustainable development strategies into university systems.

This conference is generally conducive to provide theoretical and practical examples for creating sustainable universities in a systematical and holistic approach.

Many scholars further realized the importance of green campus and carried out a large amount of research work from green school development progress, research background and management patterns, and green campus construction, etc. Taking green universities in China, Tan et al. [10] holistically and systematically studied the development process, pointed out issues such as top-level design and cooperative innovation in green campus management, and put forward corresponding suggestions and recommendations in four sections, including administrative management, propulsion, evaluation standard and action plan. In order to stimulate its sustainable development in the whole society as well as enhance residents' consciousness of sustainable development, Zhao et al. [11] from macro perspectives discussed program clauses such as concept, definition, requirements and evaluation criteria based on environmental and energy background. Muthu [12] further conducted a case study about a residential school in South India, analyzing the process of green campus construction and pointing out that green campus should simultaneously give consideration to economic, ecological and social demands.

While many concepts such as sustainable school, ecological school, green school, healthy school, high efficient school, intelligent school and seed schools have been put forward after several years' research and study [13], all special types of schools mentioned above follow three basic principles when improving the school facilities as follows and more detail information is indicated in Table II.

(1) School should be designed and constructed to reduce environmental loads in term of facilities.

(2) School should reduce environmental loads in the process of operation.

(3) School should give priority to environmental education. 
TABLE II: BASIC PRINCIPLES OF GREEN CAMPUS DESIGN

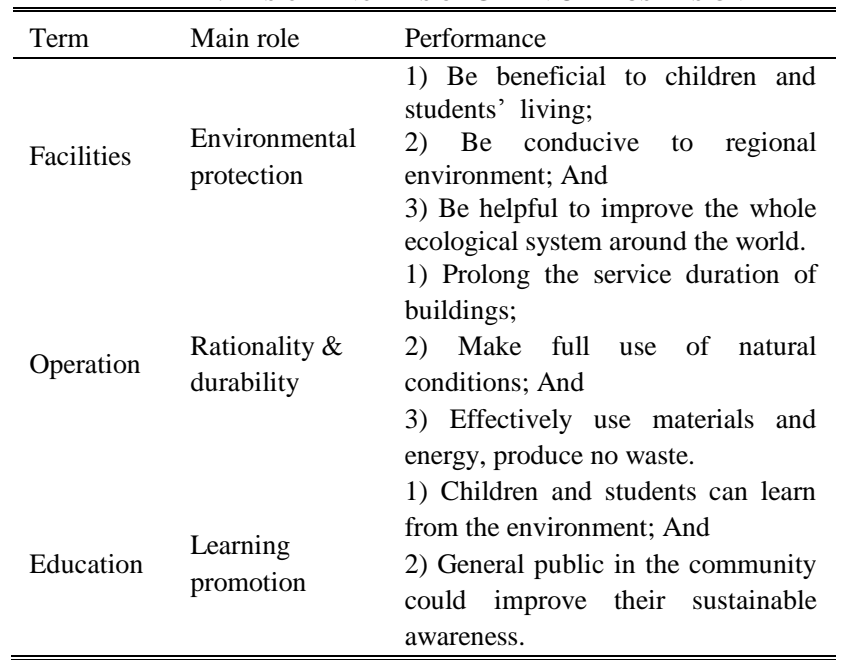

\section{ISSUES IN SUSTAINABLE CAMPUS ENVIRONMENTAL DESIGNS}

\section{A. Environmental Planning}

Both the most primary and university campuses are planned and designed in a traditional method before the introduction of green school. Namely, under the premises of both reasonable sites planning and teaching functions, school campuses generally follow the basic principle: Firstly consider the function division of architectural general planning, and then gradually design teaching buildings, athletic fields, office buildings and other auxiliaries from the perspective of the streamline layout. However, this type of design schemes always has the following deficiencies.

With regard to reasonable planning and design, many schools have not been well-planned before their establishment resulting in disorderly and unsystematic distributed facilities and infrastructures. At the same time, many schools have no long-term planning, therefore new campuses always separate from the main school yards when expanding universities and colleges, producing scattered teaching resources [14]. It is well known that site planning and design to a large content determines the working amount in field engineering. However, some schools have not fully taken use of terrain differences to arrange functions of various sections. It is not uncommon, for example, to see school sites are demolished, increasing working amount. When it comes to reorganization and expansion, some schools lack overall consideration of whole campus land planning [15]. Therefore, it is easy to surmise that green space is occupied for new building construction when building land is insufficient, compressing recreational sites, and destroying natural ventilation environment and ecological environment. Many school campuses have followed other schools' design schemes, thus school environment, spatial forms and layouts show same character tics without personalized study.

\section{B. Architectural Design}

Meanwhile, according to the field observation, many problems exist in teaching buildings, which mainly have the following features in terms of architectural design.

1) All buildings are types of gallery buildings connected by classroom unit, without any personality.
2) Classroom units have large width and long depth, resulting in poor day lighting and ventilation effects.

3) Most of school classrooms have poor soundproof effect, interfering with the adjacent classroom student learning.

4) Relevant energy-saving design and campus environmental design are seldom.

5) Although some school buildings have been designed based on sustainable methods, many of them have less education significance to students due to lack of land-saving, water-saving, material-saving or indoor environmental design.

\section{Main Reasons of Less Sustainability}

Modern school buildings have experienced three main stages from adaption, to humanity and later to ecology. However, some campuses in developing countries including China show less response to sustainability, and main reasons are summarized as follows [16]:

1) The concept of sustainable campus starts relatively late in some developing counties and China introduced this kind of concept in 1996. Although green school project has been developed and promoted for several years and achieved some progresses, a systematic guideline and design method has not been well-established. In design and construction, most schools have not been designed in a sustainable approach and while some ones have employed sustainable design methods, they just simply copy design methods and technologies of other schools, showing lower economic feasibility.

2) Due to shortage of investment in teaching buildings, buildings in primary and secondary school receive insufficient maintenance, causing to the fact that students study in dilapidated building [17]; further their personal safety cannot be satisfied in front of natural disasters such as earthquake, not to mention ecological planning and design of campus buildings.

3) In addition, general public hold a biased and unilateral understanding towards sustainable campus. When improving school environment, more trees and school greening work are always highlighted. From the perspective of design, green school construction does not only mean simply planting trees, but also consider the overall relationship between architecture and school environment [18]. Campus planning and single building green design bring ecological education significance to students in reducing investments of construction and management.

\section{Strategies of Sustainable Environmental Design}

To achieve the overall sustainability of campus environment, many aspects should be taken into consideration, such as site selection and development, natural conditions, heat island effect, drainage design etc. As for sustainable environmental design, it is essential to select sites that have not been polluted. Before the creating of green campus, sites have to be detected and observed, and areas are expected to be dealt with if they are polluted. In general, land quality is recommended to meet the requirements of environmental agency, so as to protect children and students from pollutants. Concepts related to sustainable environmental design are discussed as follows:

1) Site selection and development

In order to avoid development of inappropriate sites and 
reduce impacts of construction on environment, sites without sensitive elements and restricted type should be given priorities [19]. Choosing an appropriate site to construct campus will minimize impact on the environment sensitive areas.

\section{2) Natural conditions}

Campus design should reduce the influence of school to local climate [20], human and wildlife habitat to a minimum extent. Therefore, landscape planting is available to provide shade to site construction as well as supply high reflective materials for hard ground surface [21]. In addition, green building surface can also be considered to replace bare building surface (including roofs, roads and sidewalks). All these measures could reduce the absorption of heat as well as the consumption of refrigeration power.

3) Natural ventilation

Good natural ventilation in a community can improve comfort of outdoor environment, and speed up the outside heat dissipation and pollutant emissions, so as to provide residents with comfortable and healthy environment [22]. At the same time, reasonable planning of residential area can effectively alleviate heat island effect, reducing building energy consumed by air-conditioning. Therefore, in campus planning and building design, natural ventilation should be emphasized.

\section{CASE STUdy OF WIND ENVIRONMENT}

With the continuous research on wind environment, architects and engineering have widely approved that natural ventilation is an effective measure to save energy and provide healthy living quality. Natural ventilation could be divided into indoor natural ventilation and outdoor one [23]. As for the former one, air conditioning and refrigeration system adopted to regulate indoor thermal environment and air quality could be partly and even totally replaced, reducing indoor energy consumption without the reduction of thermal environment [24]. On a macro level, outdoor natural ventilation show a more significant role in regional environment adjustment. Firstly, natural ventilation is an approach to achieve healthy environment and this is related to campus planning. Pollutants in the air are dispersed by the wind and it is hard to be eliminated if air pollutants are blocked by high density buildings [25]. Therefore, only by reasonable building layout can we gain a good air quality. Considering pedestrians' behaviors and human being comforts, wind environment could both make an individual feel very pleasure and unpleasant. In hot summer, bursts of breeze can let pedestrians feel better, while cold wind will make them frigid in winter. Therefore, through outdoor wind environment analysis, various functional areas could be easily arranged and verified according to pedestrian behaviors.

This section will use a middle school in the southern China as the research object (Fig.1), exploring the changes of wind environment on the campus after reconstruction. The teaching buildings, library, dormitory, canteen and gymnasium are scattered point distribution. The buildings are low-rise buildings, stretching about 300 meters from the North to the South and 230 meters from the East to the West. The simplified model was established with a ratio of $1: 1$, where the height of teaching buildings are from $16 \mathrm{~m}$ to $24 \mathrm{~m}$, library is $10.2 \mathrm{~m}$, dormitory is $20 \mathrm{~m}$ and $24 \mathrm{~m}$, canteen is $12 \mathrm{~m}$ and gymnasium is $5 \mathrm{~m}$ height. Before numerical simulation of the wind environment, we first need to determine the effective computational domain. Rational computational domain helps to improve simulation accuracy and reduce complexity. After much research and calculation, the region size in this paper was selected as $600 \mathrm{~m} \times 500 \mathrm{~m} \times 80 \mathrm{~m}$. Since the result of the numerical simulation is more detailed and insightful than the field measurements and wind tunnel test, it has been widely used for this research. In this experiment, CFD method is utilized to do calculations and analysis of the building wind environment on the campus [26]. The results show that the building renovation program really helped to improve the environment and enhance the campus wind comfort.

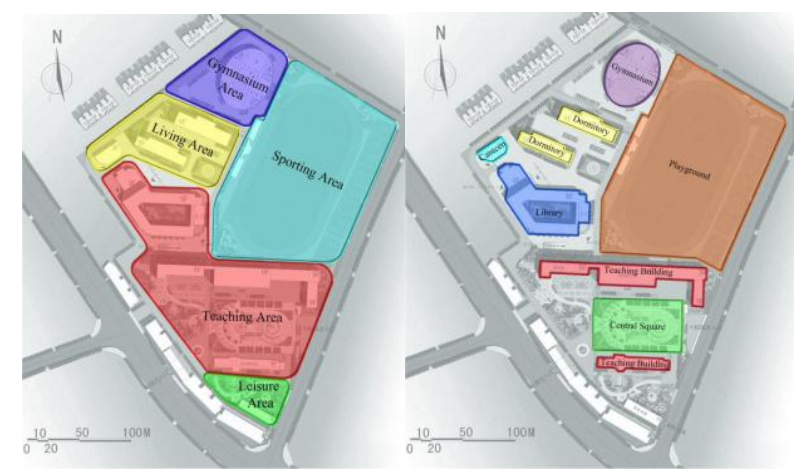

Fig. 1. Layout and buildings in secondary school in Wuhu, China.

\section{A. Local Environment}

This school campus is located in Hefei, in southeast China. The meteorological data of the city is taken as external conditions. The temperature is high in summer and low in winter. Both seasons last as long as four months, while spring and autumn are mild and short. The wind direction has significant seasonal variations, which is typical of sub-tropical moist monsoon climate. The annual average temperature between $15-16^{\circ} \mathrm{C}$, annual sunshine is about 2000 hours, the average humidity is $13-17 \mathrm{hPa}$ from the North to South, and annual average wind speed is between $1.6-3.3 \mathrm{~m} / \mathrm{s}$. Prevailing winds blow from the Southeast in summer, the Northeast in winter and the East in spring and autumn. The experiment uses CFD software to simulate the wind environment around the buildings in summer and winter. The climate conditions of the city can be seen in Table III.

TABLE III: ClimATE CONDITIONS OF THE CITY (AVERAGE VALUE)

\begin{tabular}{lll}
\hline \hline Meteorological elements & Summer & Winter \\
\hline Temperature (K) & 301 & 276 \\
Assistant channel & 78 & 74 \\
Atmospheric Pressure (hPa) & 993 & 1023 \\
Wind Speed(m/s) & 2.8 & 2.6 \\
Wind Direction & Southeast & Northeast \\
\hline \hline
\end{tabular}

\section{B. Analysis of Building Wind Environment of the Middle School}

Wind environment simulation around the campus buildings after the transformation, both in the winter and summer is 
emphatically researched. The classroom buildings, library, dormitory, canteen and other architectural models were imported to CFD in accordance with the geometric size. Ambient wind directions were to the Southeast in summer and Northeast in winter. Wind velocities were set to $2.8 \mathrm{~m} / \mathrm{s}$ and $2.6 \mathrm{~m} / \mathrm{s}$. After calculation, the wind velocity vector maps of different heights are given.

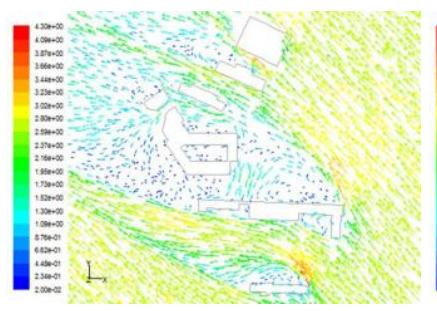

(a)

Fig.2. Wind velocity: (a) at $5 \mathrm{~m}$ height in summer (b) at $15 \mathrm{~m}$ height in summer.

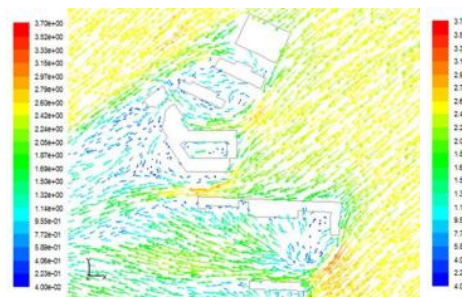

(a)

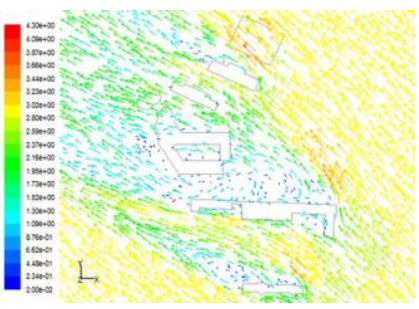

(b)

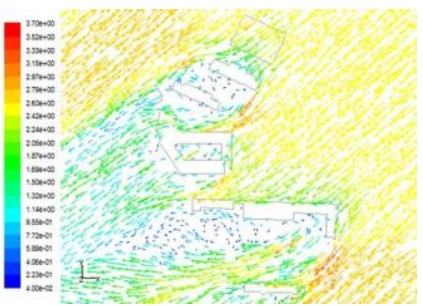

(b)

Fig.3. Wind velocity: (a) at $5 \mathrm{~m}$ height in winter (b) at $15 \mathrm{~m}$ height in winter.

Fig. 2 and Fig. 3 are respectively wind vector maps around the buildings at $5 \mathrm{~m}$, and $15 \mathrm{~m}$ height in the summer and winter. Wind velocity in most of the region during summer is between $0.2-4.7 \mathrm{~m} / \mathrm{s}$, and does not exceed $6.5 \mathrm{~m} / \mathrm{s}$. In winter, wind speed is between $0.04-3.7 \mathrm{~m} / \mathrm{s}$. According to Beaufort scale (Table IV) and HUNT standard, the wind is in a comfortable range. As shown, due to occlusion of the buildings on the leeward side of the building, existing significant wind shadow area, and the wind speed dropped dramatically. Buildings at the rear are blocked, so its windward side is in the wind shadow zone. From comparison, it is clear to see that as the height increases, the building reduces, and the ventilation effect improves.

TABLE IV: BEAUfORT SCALE AND HUMAN FEELING

\begin{tabular}{llll}
\hline \hline Beaufort number & Description & Wind speed & Human feeling \\
0 & Calm & $<0.5$ & \\
1 & Light air & $0.5 \sim 1.7$ & \\
2 & Light breeze & $1.8 \sim 3.3$ & No obstacle \\
3 & Moderate & $3.4 \sim 5.0$ & \\
4 & Moderate & $5.1 \sim 6.0$ & \\
& breeze & $6.1 \sim 7.8$ & Most people feel \\
5 & Fresh & $7.9 \sim 9.0$ & unaffected \\
6 & Strong & $10.7 \sim 10.6$ & \\
& & $13.7 \sim 15.0$ & Can act as their will \\
7 & Near gale & $15.1 \sim 16.9$ & Reach safe walking \\
& & & \\
\hline \hline
\end{tabular}

Buildings in the case can be seen as scattered-point layout. Scatter layout is common in low-rise independent homes, multi-point and high-rise flats. Since these types of buildings are designed around the center architecture, public green space or water, this kind of layout is beneficial to ventilation. The buildings lie at an angle between 30-50 degrees to the wind in both summer and winter, which not only ensures good ventilation of buildings, but also avoids the formation of air directly through the building or discomfort from a large air duct.

From the figure, in the summer, due to the small volume of the South teaching building, it barely reduces the wind blowing towards buildings on the North side of the central square. This airflow ensures ventilation of the classrooms and the center square, as well as provides good conditions for student learning and outdoor activities. During winter, due to the "L" shape of the teaching buildings on the North side of the central square, the building obstructs the cold, Northeasterly wind from blowing on the center square and the building in the Southside. This is conducive to building energy efficiency and student outdoor activities.

Before the campus transformation, the direction of the road between the canteen and office building was consistent with the wind direction in winter, and there existed no obstruction in the upwind region. A wind duct was easily formed, causing discomfort to pedestrians. In the new layout, this road has been moved slightly to the North, just in the shadow zone of the dormitory, which reduces the wind speed to a certain extent. A quadrangle is also added to the new planning, forming a closed space in the center with slow air flow. This area can be used for some special outdoor events.

Fig. 4 is a simulation of wind pressure on buildings and ground surface. As the figure shows, most of the windward and side areas of the buildings have positive pressure, while the leeward areas of the building appear to have mainly negative pressure. Fig. 5 show, respectively, pressure distribution around campus buildings at $5 \mathrm{~m}$ and $15 \mathrm{~m}$ height in summer and winter. This correlation shows that as the altitude increases, the impact on wind pressure caused by buildings reduces, the pressure difference between the windward and leeward sides of the building decreases, and the ventilation effect declines. As a whole, ventilation in the teaching area is conducive to a comfortable classroom air circulation.

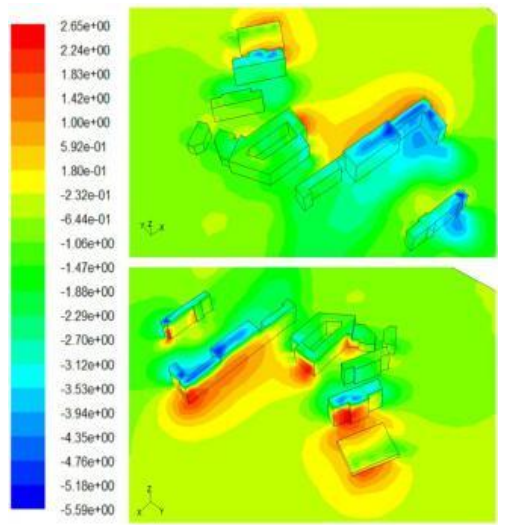

Fig. 4. Wind pressure distribution against on buildings in winter.

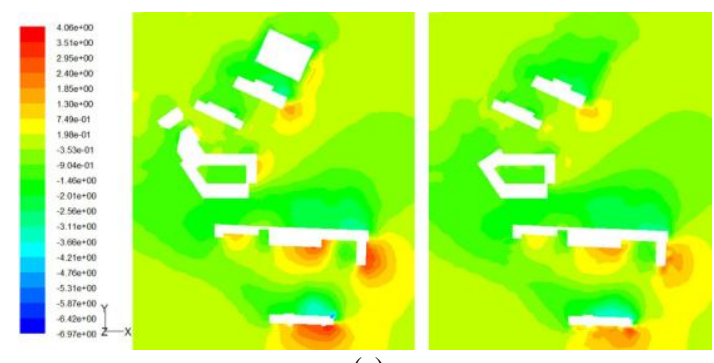

(a) 

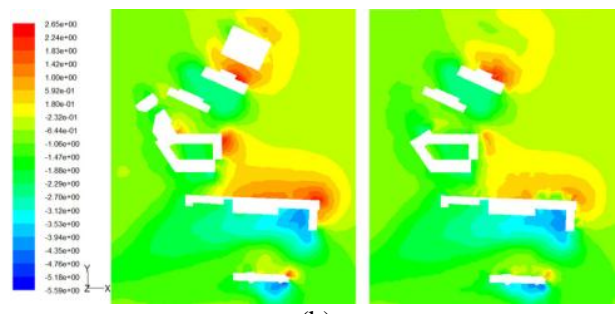

(b)

Fig. 5. Wind velocity: (a) at $5 \mathrm{~m}$ height in winter (b) at $15 \mathrm{~m}$ height in winter.

\section{CONCLUSIONS}

Based on the theory of green building, this article has combined the green environmental design methods and campus environmental design, aiming to firstly provide a healthy and comfortable environment for students and secondly improve students' and general publics' awareness and understanding of sustainable development. Based on the summary of the development and progress of green campus project all over the world, it is easy to conclude that sustainable campus should meet three basic requirements of facilities, operation and education. Furthermore, the issues and problems existing in school campus have been analyzed based on literature review and field observation, and some possible reasons for and environmental design solutions to these problems have been given. In order to further understand the environmental design in green campus design, a case study of a secondary school in Wuhu, China has been conducted in terms of wind environment based on CFD methods. In general, research and analysis work in this article could provide theoretical and practical reference for green campus environmental design.

\section{ACKNOWLEDGMENT}

This work was financially supported by national science foundation of China 51178313/E0801 and 51378365.

\section{REFERENCES}

[1] K. A. Komnitsas, "Potential of geopolymer technology towards green buildings and sustainable cities," Procedia Engineering, vol. 21, pp. 1023-1032, 2011.

[2] D. X. Zhao, C. Johnson, and B. Mou, "Social problems of green buildings: From the humanistic needs to social acceptance,' Renewable and Sustainable Energy Reviews, vol. 51, pp. 1594-1609, 2015.

[3] L. Yang, B. J. He, and M. Ye, "The application of solar technologies in building energy efficiency: BISE design in solar-powered residential buildings," Technology in Society, vol. 38, pp. 111-118, 2014.

[4] C. J. Kibert, Sustainable Construction: Green Building Design and Delivery, John Wiley \& Sons, 2012.

[5] G. R. Richardson and J. K. Lynes, "Institutional motivations and barriers to the construction of green buildings on campus: A case study of the University of Waterloo, Ontario," International Journal of Sustainability in Higher Education, vol. 8, no. 3, pp. 339-354, 2007.

[6] L. Yang, Green Building Design: Wind Environment of Building, Shanghai: Tongji University Press, 2014.

[7] D. X. Zhao and F. Q. Meng, "The green school project: A means of speeding up sustainable development?" Geoforum, vol. 65, pp. $310-313,2015$

[8] I. Thomas, "Sustainability in tertiary curricula: what is stopping it happening?" International Journal of Sustainability in Higher Education, vol. 5, no. 1, pp. 33-47, 2004

[9] D. P. Rico and M. C. Arias, "A reverse osmosis potable water plant at Alicante University: first years of operation," Desalination, vol. 137, no. 1, pp. 91-102, 2001.
[10] J. Wasley, "The Gaylord Nelson studio: Student work and faculty activism 2003-2005," in Proc. the ASME International Solar Energy Conference, 2006

[11] J. Gonchar, Yale University Sculpture Building and Gallery, Connecticut, Architectural Record, 2008.

[12] J. M. McKnight, Arizona State University ISTB 1, Arizona, Architectural Record, 168, 2008.

[13] M. McIntosh, "State of the campus environment: A national report card on environmental performance and sustainability in higher education," National Wildlife Federation, 2001.

[14] M. James and K. Card, "Factors contributing to institutions achieving environmental sustainability," International Journal of Sustainability in Higher Education, vol. 13, no. 2, pp. 166-176, 2012

[15] L. Matson, Sustainability Tracking, Assessment \& Rating System (STARS): A Tool for Evaluating Campus Sustainability, 2008.

[16] H. Tan, S. Chen, Q. Shi, and L. Wang, "Development of green campus in China," Journal of Cleaner Production, vol. 64, pp. 646-653, 2014

[17] N. Muthu, B. Shanmugam, P. Gopalsamy, and G. A. Edwin, "Implementing a holistic and student centered outreach programme towards integrated sustainable development of the campus - A case study of a residential school from South India," Integrating Sustainability Thinking in Science and Engineering Curricula, pp. 591-612, Springer International Publishing, 2015.

[18] L. Yang, B. J. He, and M. Ye, "Application research of ECOTECT in residential estate planning," Energy and Buildings, vol. 72, pp 195-202, 2014.

[19] K. Terlouw, "Iconic site development and legitimating policies: The changing role of water in Dutch identity discourses," Geoforum, vol. 57, pp. 30-39, 2014.

[20] G. Luber and M. McGeehin, "Climate change and extreme heat events," American Journal of Preventive Medicine, vol. 35, no. 5, pp. 429-435, 2008.

[21] S. M. Wheeler, "State and municipal climate change plans: the first generation," Journal of the American Planning Association, vol. 74 no. 4, pp. 481-496, 2008.

[22] F. Qian, "Analysis of energy saving design of solar building-take Tongji University solar decathlon works for example," Applied Mechanics and Materials, vol. 737, pp. 139-144, 2015.

[23] T. Van Hooff and B. Blocken, "Coupled urban wind flow and indoor natural ventilation modelling on a high-resolution grid: A case study for the Amsterdam Arena stadium," Environmental Modelling \& Software, vol. 25, no. 1, pp. 51-65, 2010.

[24] L. Yang and M. Ye, "CFD simulation research on residential indoor air quality," Science of the Total Environment, vol. 472, pp. 1137-1144, 2014.

[25] B. Blocken, T. Stathopoulos, and J. Carmeliet, "CFD simulation of the atmospheric boundary layer: wall function problems," Atmospheric Environment, vol. 41, no. 2, pp. 238-252, 2007.

[26] C. A. Halstead, "Air pollution and relief in the Glasgow area," Geoforum, vol. 4, no. 2, pp. 67-72, 1973.

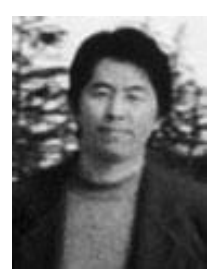

Feng Qian is a professor and doctoral adviser in College of Architecture \& Urban Planning, Tongji University, Key Laboratory of Ecology and Energy Saving Study of Dense Habitat. His research direction is sports architecture and architecture conservation

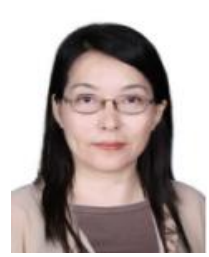

Li Yang is a professor and doctoral adviser in College of Architecture \& Urban Planning, Tongji University, Key Laboratory of Ecology and Energy Saving Study of Dense Habitat.

She is a council member in Physics Branch of the Architectural Society of China. Her research direction is green building design and building energy saving. She presided the National Natural Science Foundation of China, Shanghai International Science and Technology Cooperation Funds. She published more than 50 academic papers by Influential Chinese and International Journals. She obtained National Invention Patents and awarded the Second Prize for "Science and Technology Progress" of Architectural Society by China. 